\title{
Effects of zinc application strategy on zinc content and productivity of chickpea grown under zinc deficient soils
}

\author{
Legesse Hidoto $^{1,2}$, Walelign Worku² ${ }^{2}$, Hussein Mohammed $^{2}$ and BunyaminTaran ${ }^{3}$ \\ ${ }^{1}$ Southern Agricultural Research Institute, P. O. Box 6, Hawassa, Ethiopia. ${ }^{2}$ Hawassa University, School of \\ Plant and Horticultural Sciences, P. O. Box 5, Hawassa, Ethiopia. ${ }^{3}$ Crop Development Centre, Department of \\ Plant Sciences, University of Saskatchewan, 51 Campus Drive, Saskatoon, SK S7N 5A8, Canada.
}

*Corresponding author: walelignworku@yahoo.co.uk

\begin{abstract}
Field experiments were conducted at three locations with $\mathrm{Zn}$ deficient soils in southern Ethiopia during 2012 and 2013 cropping seasons to evaluate the effects of $\mathrm{Zn}$ fertilization strategies and varietal differences on $\mathrm{Zn}$ content and plant performance of chickpea (Cicer arietinum L.). Factorial combinations of three Zn fertilization strategies and five varieties were laid out in a randomized complete block design with three replications in each location and year. A combined analysis of variance was made using a mixed effects model. Zinc foliar application increased grain Zn content by 21 and $22 \%$ over $\mathrm{Zn}$ soil application and seed priming, respectively. The improvements were around four folds for straw $\mathrm{Zn}$ content for the same comparisons. Effects of $\mathrm{Zn}$ application strategies on gain and straw $\mathrm{Zn}$ contents were consistent across locations. The grain $\mathrm{Zn}$ concentration varied among the varieties ranging from $34 \mathrm{mg} \mathrm{kg}^{-1}$ for Mastewal to $42 \mathrm{mg} \mathrm{kg}^{-1}$ for the Landrace and variety Arerti. $\mathrm{Zn}$ application strategies did not affect the growth and yield parameters, except for pod bearing branches. Foliar $\mathrm{Zn}$ application and appropriate variety selection are potential approaches for $\mathrm{Zn}$ biofortification in chickpea. Further study aimed at identifying most effective spray timing for maximum grain quality response would be worthwhile to cut fertilizer and application costs.
\end{abstract}

Keywords: Zinc fertilizer, application strategy, varieties, biofortification, chickpea 


\section{Introduction}

Chickpea is an important pulse crop widely used for food and fodder throughout the world. Among all pulse crops, the world's chickpea consumption is second only to dry beans and has shown an increase of $33.5 \%$ in area and $65.5 \%$ in volume of production since 2008 (FAOSTAT, 2015). Ethiopia is the largest producer of chickpea in Africa accounting for about $46 \%$ of the continent's production between 1994 and 2006 (MoA, 2014). The country is also the fifth largest producer of chickpea worldwide (FAOSTAT, 2015). During the period of 1996-2005, total acreage, production and productivity of chickpea in Ethiopia had increased by $41 \%, 217 \%$ and $122 \%$, respectively (CSA, 2015).

Chickpea is high in protein, low in fat and sodium, cholesterol free and is an excellent source of both soluble and insoluble fiber, complex carbohydrates, vitamins, folate, and minerals especially calcium, phosphorus, iron, zinc and magnesium (Nwokolo and Smartt, 1996). These facts have made chickpea a potential staple food to help reduce micronutrient deficiencies in humans globally. Micronutrient deficiency also known as hidden hunger is a worldwide problem prevalent on more than half of the world population, particularly in developing countries (Mayer et al., 2008) affecting mostly women, infants, and children (Kaya et al., 2009). Hotz and Brown (2004) reported that $\mathrm{Zn}$ deficiency affects, on average, one-third of the world population, ranging from 4 to $73 \%$ in different countries. Low dietary intake of $\mathrm{Fe}$ and $\mathrm{Zn}$ appears to be the major reason for the widespread prevalence of $\mathrm{Fe}$ and $\mathrm{Zn}$ deficiencies in human populations (Cakmak, 2010).

Ethiopia has one of the highest rates of malnutrition in the world, which comprises about $52 \%$ of the country's rural population particularly children and women who fail to meet minimum requirements for calories
(CIFSRF, 2012). Micronutrient deficiency remains a significant public health burden in the country with deficiencies in iron, vitamin $\mathrm{A}$, folic acid, iodine and zinc as the common deficiencies (UNICEF, 2014). The problem is more acute in southern Ethiopia where the livelihoods and diets are heavily dependent on cereals and root crops, which are relatively low in micronutrients and high in carbohydrates. In countries with high incidence of micronutrient deficiencies, cereal-based foods represent the largest proportion of the daily diet (Cakmak, 2008).

Effective biofortification strategies need to be identified and implemented in order to enrich the micronutrient content in the staple crops especially in developing countries. Fertilizer application is one of the agronomic approaches that can help to enhance the nutrition security through improving the quality of grains in addition to its role in increasing productivity (Pathak et al., 2012; Márquez-Quiroz et al., 2015). Soil zinc deficiency is common in most of the chickpea growing areas of the world (Khan et al., 2000). Zinc deficiency is not only the cause of low productivity of the crops, but it also results in low $\mathrm{Zn}$ concentration in seeds, which leads to poor dietary $\mathrm{Zn}$ intake when consumed (Pathak et al., 2012). Concentration of micronutrients in grains has been improved with varying applications of micronutrients in various pulses (Brennan et al., 2001; Mohammad et al., 2011; Pathak et al., 2012). However, fertilizer delivery methods may vary in convenience, effectiveness and cost. Among many others, foliar spray, soil application and seed treatment are found to be effective application practices for some micronutrients (Melash et al., 2016). Each method has the potential to influence the extent of micronutrient concentration both in the treated plant directly and indirectly through enrichment of the seeds by micronutrient treatment of the 
parent (Johnson et al., 2005). Much of the research on crop responses to foliar fertilization was done on soybean (Glycine max L.), wheat (Triticum aestivum L.) (Fageria et al., 2009) and rice (Oryza sativa L.) (Guo et al., 2016) with only limited studies on chickpea. Foliar $\mathrm{Zn}$ application increased grain and straw Zn concentration in chickpea (Pathak et al., 2012). Soil $\mathrm{Zn}$ application also had positive effect on grain Zn concentration (Kaya et al., 2009), and grain and shoot Zn contents in chickpea (Shivay et al., 2014). On the other hand, soil fertilization with $\mathrm{Zn}$ has no effect on $\mathrm{Zn}$ concentration in chickpea and lentil (Lens culinaris Medik.) seeds (Johnson et al., 2005). Seed hydro-priming with $\mathrm{Zn}$ increased chickpea $\mathrm{Zn}$ concentration in seeds (Arif et al., 2007; Harris et al., 2008). In contrast, Johnson et al. (2005) reported that priming seeds with $\mathrm{Zn}$ solution had no effect on micronutrient content of the progeny seeds in chickpea and lentil, and even prevented germination of chickpea in one year. In addition to the inconsistency in the reported results, no study has been done to compare the response of chickpea or other pulses to different $\mathrm{Zn}$ application strategies.

Crop responses to micronutrient fertilization in terms of productivity has been mixed. In chickpea, grain yield increased with the application of $\mathrm{Zn}$ through foliar spraying (Pathak et al., 2012), soil application (Kaya et al., 2009) and by seed priming (Harris et al., 2008). On the other hand, Johnson et al. (2005) did not find grain yield improvement neither from $\mathrm{Zn}$ seed priming nor from soil $\mathrm{Zn}$ fertilization in chickpea and lentil. In summer maize (Zea mays L.) Zn applied as both basal and foliar spray increased the grain yield with application rates varying between locations (Liu et al., 2016).

In general, the micronutrient content of crops has received less attention and crop selection took place with little or no regard for the mineral and other micronutrient components of the seeds that may cover a very large part of the human diet (Ray et al., 2014). Variations in $\mathrm{Zn}$ concentration and discrepancies in the extent of response to $\mathrm{Zn}$ application have been observed among chickpea genotypes (Khan et al., 2000; Bueckert et al., 2011; Diapari et al., 2014; Ray et al., 2014). For instance, Bueckert et al. (2011) observed that in addition to differences in grain $\mathrm{Zn}$ concentration among individual genotypes, the kabulis have superior $\mathrm{Zn}$ concentration than the desi types. Potential variations in seed $\mathrm{Zn}$ concentration and crop performance in response to $\mathrm{Zn}$ application methods among the desi and kabuli chickpea genotypes currently under production in Ethiopia have not been examined. Thus, the objectives of the study were: 1) to compare Zn fertilizer application strategies on chickpea grain and straw $\mathrm{Zn}$ concentrations and the overall crop productivity and 2) to examine variability among the desi and kabuli chickpea varieties for grain and straw $\mathrm{Zn}$ concentration and their possible variation in response to $\mathrm{Zn}$ application strategies.

\section{Materials and Methods}

\subsection{Description of the study areas}

Field experiments were conducted during the 2012 and 2013 cropping seasons at three locations with $\mathrm{Zn}$ deficient soils in the selected administrative districts of Southern Ethiopia. These locations were Huletegna Choroko Kebele at Halaba district, Taba Kebele at Damot Galle district and Jolle Andegna Kebele at Meskan district. The location coordinates for the three sites are $07^{\circ} 20^{\prime} 34^{\prime \prime} \mathrm{N}$ and $038^{\circ} 06^{\prime} 30^{\prime \prime}$ E for Huletegna Choroko, $07^{\circ} 01^{\prime} 01.9^{\prime \prime} \mathrm{N}$ and $037^{\circ} 53^{\prime} 57^{\prime \prime} \mathrm{E}$ for Taba and $08^{\circ} 12^{\prime}$ 25.9" $\mathrm{N}$ and $038^{\circ} 28^{\prime} 33.2^{\prime \prime} \mathrm{E}$ for Jolle Andegna. The elevations of the sites are 1807, 1915 and 1923 metres above sea level for Huletegna Choroko, Taba and Jolle Andegna, respectively. The sites receive an average annual rainfall of 774, 989 and $922 \mathrm{~mm}$ in that order. 
The mean maximum and minimum temperatures for Huletegna Choroko, Taba and Jolle Andegna were 28.6 ${ }^{\circ} \mathrm{C}$ and $13.6{ }^{\circ} \mathrm{C}, 24.9^{\circ} \mathrm{C}$ and $13.6^{\circ} \mathrm{C}$, and $27.1^{\circ} \mathrm{C}$ and $10.7^{\circ} \mathrm{C}$, respectively. Soil properties of the experiment sites and weather information during the crop growth period are presented in Tables 1 and 2, respectively.

Table 1. Soil physico-chemical properties of the experimental sites at Jolle Andegna, Taba and Huletegna Choroko in 2012 and 2013.

\begin{tabular}{lcclllllll}
\hline Location & Year & $\mathrm{pH}$ & $\begin{array}{l}\mathrm{EC} \\
(\mathrm{mmho} \\
\left.\mathrm{cm}^{-1}\right)\end{array}$ & $\begin{array}{l}\mathrm{Zn}(\mathrm{mg} \\
\left.\mathrm{kg}^{-1}\right)^{*}\end{array}$ & $\begin{array}{l}\text { Soil Zn } \\
\text { status* }\end{array}$ & $\begin{array}{l}\text { OC } \\
(\%)\end{array}$ & $\begin{array}{l}\text { Total N } \\
(\%)\end{array}$ & $\begin{array}{l}\text { Available P } \\
\left(\mathrm{mg} \mathrm{kg}^{-1}\right)\end{array}$ & $\begin{array}{l}\text { Texture } \\
\text { class }\end{array}$ \\
\hline Jolle Andegna & 2012 & 6.77 & 0.20 & 0.17 & Very low & 1.71 & 0.57 & 27.1 & SCL \\
& 2013 & 6.82 & 0.22 & 0.19 & Very low & 1.70 & 0.65 & 30.2 & SCL \\
Taba & 2012 & 6.36 & 0.05 & 0.13 & Very low & 0.99 & 0.71 & 36.5 & SL \\
Huletegna Choroko & 2013 & 6.40 & 0.07 & 0.16 & Very low & 1.10 & 0.83 & 35.6 & SL \\
& 2012 & 6.73 & 0.08 & 0.98 & Low & 1.78 & 0.44 & 37.6 & CL \\
\end{tabular}

*, Soils have low $\mathrm{Zn}$ availability when there is less than to $1.1 \mathrm{mg} \mathrm{Zn} \mathrm{kg}^{-1}$ soil (DTPA extraction) (Ankerman and Large,1974); SCL, silt clay loam; SL, silt loam; CL, clay loam.

Table 2. Monthly total rainfall (mm) during crop growth period (August to December) of 2012 and 2013 and long term average between 2000-2011.

\begin{tabular}{llllllll}
\hline Location & \multirow{2}{*}{ Year } & \multicolumn{5}{c}{ Rainfall (mm) } \\
\cline { 3 - 8 } & & August & September & October & November & December & Total \\
\hline Jolle & 2012 & 143.9 & 88 & 15.8 & 8.8 & 3.5 & 260 \\
Andegna & 2013 & 164.7 & 48.1 & 50.1 & 33.5 & 2.7 & 299.1 \\
& $2000-2011$ & 207.5 & 113.7 & 48.4 & 24 & 8.3 & 401.9 \\
Taba & 2012 & 169.7 & 135.3 & 13 & 32.6 & 16.8 & 367.4 \\
& 2013 & 178.4 & 210.2 & 149.7 & 97.3 & 2.3 & 637.9 \\
& $2000-2011$ & 152.6 & 134.3 & 69.5 & 48.8 & 41 & 446.2 \\
Huletegna & 2012 & 89.5 & 100.7 & 10 & 9 & 2.6 & 211.8 \\
Choroko & 2013 & 178.1 & 138.8 & 118.9 & 60.3 & 0.2 & 496.3 \\
& $2000-2011$ & 121.81 & 114.1 & 53.7 & 42.1 & 21 & 352.71 \\
\hline
\end{tabular}

Source: National Meteorology Agency, Addis Ababa, Ethiopia (2013). 


\subsection{Experimental treatments, design and manage- ment}

The experiment was based on factorial combinations of three $\mathrm{Zn}$ application strategies and five chickpea varieties. Zinc fertilizer application strategies consisted of foliar application, soil application and seed priming. The five chickpea varieties were composed of four improved varieties that were released between 1999 and 2007 and one local landrace. The improved varieties consisted of two desi types (Mastewal and Naatolii) and two Kabuli types (Arerti and Habru) while the land race was a desi type. The treatment combinations were arranged in a randomized complete block design with three replications. The improved varieties were previously tested for performance and were selected to expand chickpea production in southern Ethiopia. The foliar application was carried out by spraying $0.5 \% \mathrm{ZnSO}_{4} \cdot 7 \mathrm{H}_{2} \mathrm{O}$ solution three times: at early vegetative stage, at early flowering and at pod filling. The amount of $\mathrm{ZnSO}_{4} .7 \mathrm{H}_{2} \mathrm{O}$ fertilizer used for each spray was $8.93 \mathrm{~kg} \mathrm{ha}^{-1}$. For soil $\mathrm{Zn}$ application, $\mathrm{ZnSO}_{4} \cdot 7 \mathrm{H}_{2} \mathrm{O}$ at the rate of $25 \mathrm{~kg} \mathrm{ha}^{-1}$ was drilled in rows and incorporated into soil before the sowing of chickpea. Seed priming involved soaking of chickpea seeds in $0.05 \% \mathrm{ZnSO}_{4} \cdot 7 \mathrm{H}_{2} \mathrm{O}(0.45 \mathrm{~kg}$ $\mathrm{ha}^{-1}$ ) solution for 12 hours and drying the seeds under shade for ease of handling before sowing.

The chickpea seeds were sown at $40 \mathrm{~cm}$ between rows and $10 \mathrm{~cm}$ between plants spacing. Sowing took place at the end of the main cropping season: at Huletegna Choroko on 8 September 2012 and 23 August 2013, at Jolle Andegna on 20 Sepetember 2012 and 4 September 2013 and at Taba on 14 September 2012 and 17 September 2013. A week after emergence the seedlings were thinned to maintain a density of 25 plants $\mathrm{m}^{-2}$. Gross and net plot sizes for the experiments were 11.2 and $8.4 \mathrm{~m}^{2}$, respectively. Weeds were controlled by hand weeding and cultivation as frequently as required. All agronomic practices other than the treatment factors were kept uniform across all treatments.

\subsection{Data collection}

Grain and straw Zn concentration analyses were conducted at the University of Saskatchewan, Saskatoon, Canada. Subsamples of grains and straws $(25 \mathrm{~g})$ for determination of $\mathrm{Zn}$ concentration were taken randomly from the entire harvested plot of each of the three replications at each location. The samples were oven dried at $70{ }^{\circ} \mathrm{C}$ for 24 hours and a ground sample of $0.5 \mathrm{~g}$ was weighed on a balance sensitive to the nearest $0.00001 \mathrm{~g}$. The grain and straw samples from each replication were prepared by a standard $\mathrm{HNO}_{3}-$ $\mathrm{H}_{2} \mathrm{O}_{2}$ digestion method (Thavarajah et al., 2009) using wet digestion with nitric acid. Zinc concentration was measured by flame Atomic Absorption Spectrometry (AJ ANOVA 300, Lab Synergy). Zinc concentrations measured by this method were validated using NIST standard reference material 1573a. Lentil (Lens culinaris) seeds (cv, CDC Redberry) and organic wheat (Triticum aestivum) seeds were used as laboratory reference materials and were measured periodically to ensure consistency in the method.

Plant height, number of pod bearing branches and number of pods plant ${ }^{-1}$ were recorded from 10 randomly selected plants of the middle six rows in each plot. Above ground biomass and grain yield were measured from a harvest made on the middle six rows $\left(2.4 \mathrm{~m} \times 3.5 \mathrm{~m}=8.4 \mathrm{~m}^{2}\right)$ of each plot at ripening. Grain yield was adjusted to storage moisture content of $10 \%$ based on the value of actual grain moisture read by digital grain moisture tester (Hoh-Express HE-50, Pfeuffer, Germany). Grain weight was determined by counting 250 grains randomly from each plot and converting it to 1000 grain weight after adjusting to storage moisture content. Grain $\mathrm{Zn}$ yield 
$\mathrm{ha}^{-1}$ was calculated based on grain $\mathrm{Zn}$ concentration $\left(\mathrm{mg} \mathrm{kg}^{-1}\right)$ and grain yield $\left(\mathrm{t} \mathrm{ha}^{-1}\right)$.

Fifteen soil samples from a depth of $0-30 \mathrm{~cm}$ were randomly collected before sowing across each experimental site using an auger to assess the physical and chemical properties including soil $\mathrm{Zn}$ concentration. The collected soil samples were mixed together on location basis, air dried, cleaned off any stones and plant residues and were grinded in stainless steel soil grinder and allowed to pass a $2 \mathrm{~mm}$ sieve. The soil $\mathrm{Zn}$ concentration was extracted with DTPA and determined by Atomic Absorption Spectrophotometer (Lindsay and Norvell, 1978). Available P was determined by extracting the soil sample with $0.5 \mathrm{M}$ sodium bicarbonate at $\mathrm{pH} 8.5$ (Olsen and Sommers, 1982). Soil organic carbon was determined following the Walkley (1947) procedure. Details of the soil properties for the experimental fields are shown in Table 1.

\subsection{Data analysis}

Prior to combined analysis of variance, separate analysis of each location during 2012 and 2013 was carried out using general linear model of SAS software (SAS, 2008). The data were tested for homogeneity of error variance. The result of this test revealed that grain yield, above ground biomass and straw $\mathrm{Zn}$ content were heterogeneous. The regression approach has indicated that Log transformation was the appropriate method. Grain yield and above ground biomass were transformed using $\log ($ data +1$)$, while $\log$ (data) was applied for straw Zn concentration (Gomez and Gomez, 1984). All data were subjected to combined analysis of variance using the mixed effects model (SAS, 2008) where year and replication were considered random effects while location, variety and $\mathrm{Zn}$ application strategy were assigned as fixed effects. Differences among treatment means were compared using least significant difference (LSD) test at 5\% whenever effects were found significant at $\mathrm{P}<0.05$ from the analysis of variance.

\section{Results}

\subsection{Weather}

Total precipitation during the growing season $(\mathrm{Au}-$ gust-December) of 2013 was much more than either 2012 at all locations or the long term average at the two locations (Table 2). For instance, the total rainfall for the growing season at Huletegna Choroko was greater by $285 \mathrm{~mm}$ and $244 \mathrm{~mm}$ compared to 2013 and the long-term amounts, respectively. Particularly, rainfall in October and November at Jolle Andegna in 2012 was meagre with amounts about one third of the long-term averages and $31 \%$ to $26 \%$ of 2013. The amount of rainfall during the growing season in 2013 was greater by 15, 74 and 134\% at Jolle Andegna, Taba and Huletegna Choroko as compared to the year 2012, respectively. The long term rainfall also exceeded that of 2012 at Taba (43\%) and Huletegna Choroko (14\% ) but was lower at Jolle Andegna by $34 \%$. Moreover, the distribution of rainfall during the 2012 growing period was uneven with most of the days without rain and some days with less than $5 \mathrm{~mm}$ precipitation. Relatively high and evenly distributed rainfall in 2013 meant longer crop growth duration leading to larger biomass accumulation and higher grain yield compared to 2012. Location wise, Taba received the highest amount of rainfall $(367 \mathrm{~mm})$ in 2012 followed by Jolle Andegna $(260 \mathrm{~mm})$ and Huletegna Choroko (212 mm).

In 2013, all sites had adequate rainfall except Jolle Andegna (299 mm). In spite of better rainfall amount at Taba, chickpea yields were relatively low because of poor rainfall distribution in 2012 and excessive initial moisture followed by extended rainfall in 2013 . 


\subsection{Grain and straw $\mathrm{Zn}$ concentrations and grain $\mathrm{Zn}$} yield

Zinc application strategy significantly influenced both grain and straw $\mathrm{Zn}$ concentrations (Table 3). Zinc foliar application resulted in the highest grain and straw $\mathrm{Zn}$ content as compared to both soil application and seed priming and this effect was consistent across locations. Accordingly, Zinc foliar application had 21 and $22 \%$ grain $\mathrm{Zn}$ content advantage over soil application and seed priming, respectively (Table 4). Moreover, foliar application resulted in 383 and 437\% increase in straw Zn content over soil application and seed priming methods, respectively.

Grain Zn yield of chickpea also varied significantly among application strategies (Table 3 ) with foliar application having the highest grain $\mathrm{Zn}$ yield of $85 \mathrm{~g} \mathrm{ha}^{-1}$.

Table 3. Mean square values for combined analysis of variance over locations and years for grain and straw $\mathrm{Zn}$ concentration, grain $\mathrm{Zn}$ yield, grain yield, thousand grain weight, and pods per plant.

\begin{tabular}{|c|c|c|c|c|c|c|c|}
\hline Source & DF & $\begin{array}{l}\text { Grain } \\
\mathrm{Zn}\end{array}$ & Straw $\mathrm{Zn}^{\mathrm{a}}$ & $\begin{array}{l}\text { Grain Zn } \\
\text { yield }^{\mathrm{a}}\end{array}$ & $\begin{array}{l}\text { Grain } \\
\text { yield }^{\mathrm{a}}\end{array}$ & TGW & $\begin{array}{l}\text { pods per } \\
\text { plant }\end{array}$ \\
\hline Strategy (S) & 2 & $1905^{*}$ & $246764 * *$ & $0.32 *$ & 0.003 & 54 & 524 \\
\hline Variety (V) & 4 & $563 *$ & 802 & 0.20 & 0.066 & $230114^{*}$ & 7359 \\
\hline Location (L) & 2 & 1485 & 4566 & 2.39 & 0.536 & 67096 & 25145 \\
\hline $\mathrm{S} * \mathrm{~V}$ & 8 & 27 & 1000 & 0.02 & 0.005 & 165 & 354 \\
\hline$S * L$ & 4 & 17 & 1230 & 0.01 & 0.002 & 2 & 310 \\
\hline $\mathrm{V}^{*} \mathrm{~L}$ & 8 & 83 & 1514 & 0.09 & $0.029 *$ & 21821 & 3023 \\
\hline $\mathrm{S} * \mathrm{~V} * \mathrm{~L}$ & 16 & 18 & 1103 & 0.01 & 0.004 & 234 & 346 \\
\hline $\mathrm{CV}_{\%}$ & & 21.5 & (19.2) & (20.2) & $(25.8)$ & 7.5 & 23.3 \\
\hline
\end{tabular}

DF, degree of freedom; *, Significant at 5\% level; **, significant at $1 \%$ level; TGW, thousand grain weight; a, Log transformed data.

Grain $\mathrm{Zn}$ content also varied significantly among the varieties (Table 3) ranging between 34 and $42 \mathrm{mg} \mathrm{kg}^{-1}$ (Table 4).The Local landrace and variety Arerti had $19 \%$ more grain $\mathrm{Zn}$ than variety Mastewal, which had the lowest $\mathrm{Zn}$ content $\left(34 \mathrm{mg} \mathrm{kg}^{-1}\right)$ of all tested varieties (Table 4). Unlike grain $\mathrm{Zn}$ content, the variation in straw $\mathrm{Zn}$ content and grain $\mathrm{Zn}$ yield among varieties were not significant (Table 3). Location effects and their interactions were not significant for grain and straw $\mathrm{Zn}$ concentrations and grain $\mathrm{Zn}$ yield in spite of a wide variation in the later (Table 3). This was due to a highly significant location by year interaction effects against which the trait was tested for significance. 
Table 4. The effect of $\mathrm{Zn}$ application strategies and variety on grain and straw $\mathrm{Zn}$ concentrations, grain $\mathrm{Zn}$ yield, grain yield, grain weight and pods per plant of chickpea.

\begin{tabular}{|c|c|c|c|c|c|c|}
\hline Treatments & $\begin{array}{l}\text { Grain } \mathrm{Zn} \\
\left(\mathrm{mg} \mathrm{kg}^{-1}\right)\end{array}$ & $\begin{array}{l}\text { Straw Zn } \\
\left(\mathrm{mg} \mathrm{kg}^{-1}\right)^{\mathrm{a}}\end{array}$ & $\begin{array}{l}\text { Grain } \mathrm{Zn} \text { yield } \\
\left(\mathrm{gha}^{-1}\right)^{\mathrm{a}}\end{array}$ & $\begin{array}{l}\text { Grain yield } \\
\left(\text { ton } \mathrm{ha}^{-1}\right)^{\mathrm{a}}\end{array}$ & $\begin{array}{l}1000 \text { grain } \\
\text { wt }(\mathrm{g})\end{array}$ & $\begin{array}{r}\text { Pod no. } \\
\text { plant }^{-1}\end{array}$ \\
\hline \multicolumn{7}{|l|}{ Strategy } \\
\hline Soil appl. & $36.58 \mathrm{~b}$ & $23.32(1.28 b)$ & $71(1.68 b)$ & $1.88(0.41)$ & 250 & 63 \\
\hline Seed priming & $36.24 \mathrm{~b}$ & $21.02(1.26 \mathrm{c})$ & $68(1.68 b)$ & $1.84(0.41)$ & 251 & 68 \\
\hline Foliar appl. & $44.37 \mathrm{a}$ & $112.80(2.02 a)$ & $85(1.78 a)$ & $1.94(0.42)$ & 251 & 64 \\
\hline $\mathrm{SE} \pm$ & 0.91 & $1.45(0.01)$ & $9.08(0.01)$ & $0.02(0.001)$ & 1.58 & 2.79 \\
\hline $\operatorname{LSD}_{5 \%}$ & 2.47 & $(0.01)$ & $(0.05)$ & NS & NS & NS \\
\hline \multicolumn{7}{|l|}{ Variety } \\
\hline Arerti & $41.55 \mathrm{a}$ & $55.86(1.57)$ & $80(1.74)$ & $1.95(0.41)$ & $251 \mathrm{~d}$ & 65 \\
\hline Habru & $37.64 \mathrm{~b}$ & $50.83(1.52)$ & $65(1.65)$ & $1.69(0.38)$ & $303 a$ & 58 \\
\hline Mastewal & $34.11 \mathrm{c}$ & $51.89(1.47)$ & $75(1.71)$ & $2.08(0.45)$ & $273 c$ & 67 \\
\hline Naatolii & $40.19 \mathrm{ab}$ & $47.02(1.49)$ & $83(1.80)$ & $2.06(0.45)$ & $286 \mathrm{~b}$ & 52 \\
\hline Local landrace & $41.87 \mathrm{a}$ & $56.38(1.55)$ & $70(1.67)$ & $1.66(0.37)$ & $139 \mathrm{e}$ & 82 \\
\hline $\mathrm{SE} \pm$ & 1.14 & $4.98(0.04)$ & $6.42(0.04)$ & $0.14(0.02)$ & 24.00 & 5.38 \\
\hline $\mathrm{LSD}_{5 \%}$ & 3.19 & NS & NS & NS & 7.17 & NS \\
\hline \multicolumn{7}{|l|}{ Location } \\
\hline JolleAndegna & 34.42 & $43.22(1.33)$ & $75(1.61)$ & $2.12(0.41)$ & 245 & 78 \\
\hline Taba & 40.76 & $55.52(1.62)$ & $49(1.64)$ & $1.30(0.34)$ & 280 & 46 \\
\hline Huletegna $\mathrm{Ch}$. & 42.00 & $55.62(1.62)$ & $100(1.91)$ & $2.25(0.50)$ & 226 & 71 \\
\hline $\mathrm{SE} \pm$ & 6.22 & $7.95(0.10)$ & $33.56(0.26)$ & $0.82(0.12)$ & 47.44 & 27.30 \\
\hline $\mathrm{LSD}_{5 \%}$ & NS & NS & NS & NS & NS & NS \\
\hline
\end{tabular}

Means with the same letter are not significantly different at $5 \%$ level; NS, not significant; a, transformed values are given in parenthesis.

\subsection{Grain yield, seed weight and pods per plant}

Zinc fertilizer application strategy did not influence grain yield, seed weight and pods per plant (Table 3). Similarly, there was no significant difference among varieties for these traits except seed weight. The variety Habru had the largest seed weight compared to all other varieties; it has more than twofold larger seeds than the Local landrace (Table 4). The improved varieties of both kabuli and desi types had greater seed size than the Local landrace.
The location effect was not significant on any of the traits (Table 3). However, there was a significant variety by location interaction for grain yield. The interaction indicated that the two improved desi types, Mastewal and Naatolii, were particularly superior at Taba (Figure 1, A). These varieties also performed well at Jolle Andegna, which were at par with variety Arerti, a kabuli type. At Huletegna Choroko, the kabuli type Arerti was superior while the rest had similar productivity. 

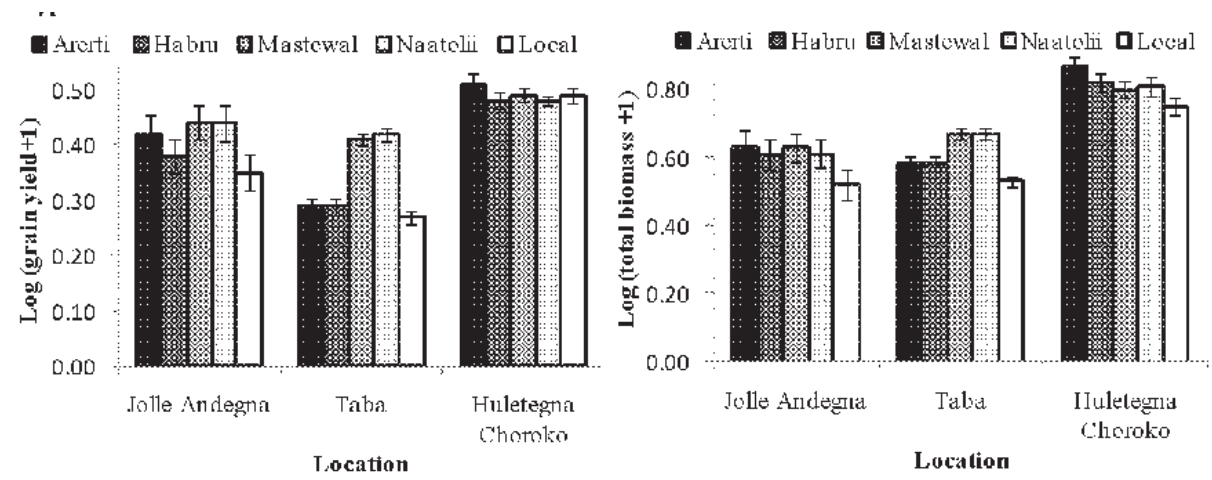

Figure 1. The location by variety interaction effects on (A) grain yield and (B) total biomass of chickpea.

3.4. Plant height, pod bearing branches, above ground biomass and harvest index

None of the traits were significantly influenced by $\mathrm{Zn}$ application strategies or varietal differences except number of pod bearing branches which varied significantly among varieties (Table 5). The varieties Arerti (kabuli), Mastewal and Local landrace (desi) produced greater number of pod bearing branches (Table 6). However, this did not translate into higher number of pods except the Local landrace, which had the highest number of pods plant ${ }^{-1}$. Performance for these traits was also similar except for a location by variety interaction for above ground biomass (Figure 1, B). The interaction showed that the improved desi type, Mastewal and Naatolii, had better performance at Taba, while the differences were not significant for the kabulis in the other two sites (Figure 1, B).
The trends expressed for total biomass were more or less similar with that of grain yield due non significant variation for harvest index among the varieties.

\subsection{Correlation and group comparison}

Grain yield did not show significant correlation either with grain $\mathrm{Zn}$ content ( $\mathrm{r}=0.06$ ) or straw $\mathrm{Zn}$ content $(r=-0.07)$. Also, grain size did not significantly associate either with grain $\mathrm{Zn}(\mathrm{r}=0.00)$ or straw $\mathrm{Zn}$ $(\mathrm{r}=0.07)$ concentrations. On the other hand, grain $\mathrm{Zn}$ concentration had a positive and significant correlation with straw $\mathrm{Zn}$ content $(\mathrm{r}=0.41 ; \mathrm{P}<0.01)$. The Local landrace had greater grain and straw $\mathrm{Zn}$ concentrations than the mean of improved genotypes though the difference was significant only for the former (Table 7). On the other hand, the kabulis and the desis had similar grain and straw $\mathrm{Zn}$ content as a group. 
Table 5. Mean square values for combined analysis of variance over locations and years for plant height, number of pod bearing branches, above ground biomass and harvest index.

\begin{tabular}{llllll}
\hline Source & DF & Plant height & $\begin{array}{l}\text { Pod bearing } \\
\text { branches }\end{array}$ & $\begin{array}{l}\text { Above ground } \\
\text { biomass }^{\mathrm{a}}\end{array}$ & Harvest index \\
\hline Strategy (S) & 2 & 26 & 8 & 0.001 & 0.007 \\
Variety (V) & 4 & 418 & $211^{* *}$ & 0.09 & 0.088 \\
Location (L) & 2 & 2787 & 4516 & 1.287 & 0.287 \\
$\mathrm{~S} * \mathrm{~V}$ & 8 & 16 & 8 & 0.026 & 0.010 \\
$\mathrm{~S} * \mathrm{~L}$ & 4 & 13 & 16 & 0.000 & 0.003 \\
$\mathrm{~V} * \mathrm{~L}$ & 8 & 42 & 42 & $0.024^{*}$ & 0.015 \\
$\mathrm{~S} * \mathrm{~V} * \mathrm{~L}$ & 16 & 9 & 8 & 0.003 & 0.008 \\
$\mathrm{CV} \%$ & & 9.3 & 25.5 & 25.3 & 14.3 \\
\hline
\end{tabular}

$\mathrm{DF}$, degree of freedom; *, significant at $5 \%$ level; **, significant at $1 \%$ level; a, Log transformed data.

Table 6. Effects of $\mathrm{Zn}$ fertilizer application strategy and variety on plant height, number of pod bearing branches, above ground biomass and harvest index

\begin{tabular}{|c|c|c|c|c|}
\hline Treatments & $\begin{array}{l}\text { Plant height } \\
(\mathrm{cm})\end{array}$ & $\begin{array}{l}\text { Pod bearing } \\
\text { branch no. }\end{array}$ & $\begin{array}{l}\text { Above ground } \\
\left.\text { biomass (ton } \mathrm{ha}^{-1}\right)^{\mathrm{a}}\end{array}$ & Harvest index \\
\hline \multicolumn{5}{|l|}{ Strategy } \\
\hline Soil appl. & 48.2 & 17 & $4.86(0.68)$ & 0.42 \\
\hline Seed priming & 47.8 & 17 & $4.76(0.67)$ & 0.43 \\
\hline Foliar appl. & 48.9 & 16 & $4.87(0.67)$ & 0.44 \\
\hline $\mathrm{SE} \pm$ & 0.15 & 0.79 & $0.07(0.01)$ & 0.01 \\
\hline $\operatorname{LSD}_{5 \%}$ & NS & NS & NS & NS \\
\hline \multicolumn{5}{|l|}{ Variety } \\
\hline Arerti & 48.4 & $18 \mathrm{a}$ & $5.39(0.69)$ & 0.39 \\
\hline Habru & 52.3 & $15 \mathrm{~b}$ & $4.86(0.67)$ & 0.39 \\
\hline Mastewal & 45.2 & $17 \mathrm{a}$ & $4.74(0.70)$ & 0.48 \\
\hline Naatolii & 49.4 & $14 \mathrm{c}$ & $4.49(0.70)$ & 0.45 \\
\hline Local landrace & 46.2 & $18 \mathrm{a}$ & $3.84(0.60)$ & 0.45 \\
\hline $\mathrm{SE} \pm$ & 1.48 & 0.43 & $0.45(0.02)$ & 0.02 \\
\hline $\mathrm{LSD}_{5 \%}$ & NS & 1.60 & NS & NS \\
\hline \multicolumn{5}{|l|}{ Location } \\
\hline Jolle Andegna & 49.2 & 21 & $4.66(0.61)$ & 0.50 \\
\hline Taba & 42.3 & 8 & $3.35(0.61)$ & 0.40 \\
\hline Huletegna Choroko & 53.4 & 20 & $6.48(0.81)$ & 0.40 \\
\hline $\mathrm{SE} \pm$ & 4.37 & 3.47 & $1.84(0.15)$ & 0.06 \\
\hline $\mathrm{LSD}_{5 \%}$ & NS & NS & NS & NS \\
\hline
\end{tabular}

Means with the same letter are not significantly different at $5 \%$ level; NS, not significant; a, transformed values are given in parenthesis. 
Table 7. Contrast means for grain and straw $\mathrm{Zn}$ concentrations.

\begin{tabular}{|c|c|c|c|c|}
\hline Component & Kabul vs & Desi & Improved vs & Local \\
\hline Grain $\mathrm{Zn}$ content $\left(\mathrm{mg} \mathrm{kg}^{-1}\right)$ & $38.72 \mathrm{a}$ & $39.60 \mathrm{a}$ & $38.37 \mathrm{~b}$ & $41.87 \mathrm{a}$ \\
\hline Straw $\mathrm{Zn}$ content $\left(\mathrm{mg} \mathrm{kg}^{-1}\right)$ & $53.34 \mathrm{a}$ & $51.76 \mathrm{a}$ & $51.4 \mathrm{a}$ & $56.38 \mathrm{a}$ \\
\hline
\end{tabular}

Contrast means with same letter are not significantly different at 5\% level

\section{Discussion}

Grain and straw Zn content of chickpea were significantly affected by Zn fertilizer application strategies. The results were consistent across locations. Foliar Zn fertilizer application resulted in significantly higher grain and straw $\mathrm{Zn}$ content as compared to soil application and seed priming. Similarly, Pathak et al. (2012) observed that there was an increase in Zn content in the grains and leaves of chickpea after foliar $\mathrm{Zn}$ application to $\mathrm{Zn}$ deficient as well as $\mathrm{Zn}$ sufficient plants. Also, Alloway (2004) observed that foliar application of $\mathrm{Zn}$ led to an increase in $\mathrm{Zn}$ content in both the grain and the vegetative parts of the plants. Application of micronutrients by foliar spray was more effective because of the small amounts required, more uniform application and efficiency of uptake by the plants compared to soil fertilization (Fageria et al., 2009). Mousavi (2011) also indicated that foliar application of micronutrients was more suitable than soil application due to the rapid availability, ease of use and reduced toxicity that could be caused by accumulation and element stabilization in the soil. Moreover, nutrient availability to plant from soil application could be reduced due to binding in the soil and restricted uptake when moisture is limiting (Yadegari, 2016). On the other hand, the need for repeated foliar applications due to poor mobility of micronutrients led to increased expenditure and extended application time.
Soil $\mathrm{Zn}$ application and seed $\mathrm{Zn}$ priming did not influence either grain or straw $\mathrm{Zn}$ concentration. Other studies have also indicated that seed priming with $\mathrm{Zn}$ may not be effective in fulfilling $\mathrm{Zn}$ requirements of different crops. For example, soil fertilization with $\mathrm{Zn}$ has no effect on $\mathrm{Zn}$ content of chickpea and lentil seeds (Johnson et al., 2005). Moreover, Johnson et al. (2005) reported that $\mathrm{Zn}$ primed seeds have no effect on micronutrient contents of the progeny seeds in chickpea and lentil and hampered germination of chickpea in one year. On the other hand, soil Zn application had a significant positive effect on grain $\mathrm{Zn}$ concentration (Kaya et al., 2009) and grain and shoot Zn content (Shivay et al., 2014) in chickpea. Also, seed hydro-priming with $\mathrm{Zn}$ increased chickpea $\mathrm{Zn}$ content (Harris et al., 2008; Arif et al., 2007).

In this study, $\mathrm{Zn}$ concentration in the straw was highly enriched by foliar application when compared to the grain $\mathrm{Zn}$ owing to the mechanism of ion uptake. Zinc from foliar application penetrates the cuticle and the cellulose wall via limited or free diffusion (Franke, 1967) and ions are also absorbed through the stomata on the leaves (Eichert and Burkhardt, 2001).The altered subcellular compartmentation of $\mathrm{Zn}$ in the shoot enhances more efficient biochemical utilization of $\mathrm{Zn}$ in cells of the shoot while only part of the nutrient can be translocated from the shoot to the grain (Franke, 1967). Also, most of the micronutrients mobility in plant tissues is poor unlike macronutrients (Fageria 
et al., 2009). Straw obtained from crops grown on nutrient deficient soils may also be deficient with the same nutrients (Nube and Voortman, 2006), which in turn causes nutrient deficiency in animals that fed on this straw (Rengel et al., 1999). Chickpea plants foliar sprayed with $\mathrm{Zn}$ had greater straw Zn concentration compared to the grain, which could contribute in preventing human $\mathrm{Zn}$ deficiency through consuming the animals that fed on the straw (Cakmak, 2002).

The tested varieties differed for grain $\mathrm{Zn}$ content while contrast comparison between desi and kabuli was not significant for either grain or straw $\mathrm{Zn}$ content, indicating the importance of focusing on individual selection. Variation in grain $\mathrm{Zn}$ concentration among chickpea genotypes was previously reported (Khan et al., 2000; Kaya et al., 2009; Bueckert et al., 2011; Diapari et al., 2014; Ray et al., 2014). Responses to $\mathrm{Zn}$ applications were variable depending on the genotypes (Khan et al., 2000), which is not the case in our study. Moreover, Bueckert et al. (2011) reported that the kabulis had better grain $\mathrm{Zn}$ concentration than the desis in a study involving four kabuli and six desi genotypes. Grain and straw Zn contents were positively correlated, which indicated selection for high grain $\mathrm{Zn}$ content may ensure greater $\mathrm{Zn}$ concentration in the straw. On the other hand, neither grain nor straw $\mathrm{Zn}$ concentrations were correlated either with grain yield or grain weight. Diapari et al. (2014) also reported that association of $\mathrm{Zn}$ content with grain weight was mostly not significant though it was negatively associated with grain yield among 94 genotypes.

The $\mathrm{Zn}$ fertilizer application strategies did not influence most of the growth and productivity parameters in this study. Findings on the effect of $\mathrm{Zn}$ fertilization on plant growth and yield are mixed. Grain yield has increased with the application of $\mathrm{Zn}$ through foliar spraying (Pathak et al., 2012), soil application (Kaya et al., 2009) and seed priming (Harris et al., 2008), in chickpea. On the other hand, Johnson et al. (2005) did not find grain yield response neither from $\mathrm{Zn}$ seed priming nor from soil fertilization with $\mathrm{Zn}$ in chickpea and lentil. Source of variation among reported results could be differences in initial soil $\mathrm{Zn}$ content, prevalence of limiting factors other than $\mathrm{Zn}$, genotype variation and differences in timing, frequency and rate of $\mathrm{Zn}$ application.

The tested chickpea varieties did not vary on growth and yield parameters except for number of pod bearing branches and grain weight. However, varietal performance has not been consistent across locations following a significant interaction with locations. Previous tests have also shown that the five tested varieties differed in productivity across locations (Beyene et al., 2013) though variety rankings were not consistent. Average productivity of the varieties has been low compared to their potential especially at Taba. This was because of a very low performance in 2012 due to poor rainfall amount and distribution and further yield drop at Taba in 2013 because of excess rainfall during early establishment since the crop is sensitive to waterlogging (Hawando, 1987).

\section{Conclusions}

The study showed that foliar $\mathrm{Zn}$ spraying is an effective method for biofortification of chickpea compared to soil application and seed priming. Foliar application has even greater advantage for improving straw $\mathrm{Zn}$ concentration, thereby, improving animal feed quality, which could in turn improve human nutrition. On the other hand, none of the $\mathrm{Zn}$ application strategies influenced most of the growth and productivity parameters. Varietal differences were observed for grain $\mathrm{Zn}$ concentration showing the potential use of genotype selection for improving $\mathrm{Zn}$ availability in human diets. Based on the results, foliar application of $0.5 \% \mathrm{ZnSO}_{4} \cdot 7 \mathrm{H}_{2} \mathrm{O}$ at the specified times and the use of varieties such as Naatolii and Arerti can be recommended as a $\mathrm{Zn}$ 
biofortification strategy for chickpea in Ethiopia. On the other hand, though fertilizer requirement for repeated spraying is nearly similar to that of soil fertilization it would be still too costly to farmers, especially in the absence of yield response. Thus, a study aimed at identifying the most effective spray timing for maximum response of grain quality would be worthwhile as a first step. On the other hand, fertilization with $\mathrm{Zn}$ alone may not enhance the productivity of chickpea in southern Ethiopia perhaps due to the prevalence of other limiting elements, which needs further research on the effects of $\mathrm{Zn}$ in conjunction with other micronutrients.

\section{Acknowledgements}

The authors would like to acknowledge the Canadian International Food Security Research Fund (Project no.106927-001/2) for financing the study.

\section{References}

Alloway, B.J. 2004. Zinc in soils and crop nutrition. IZA Publications. International Zinc Association, Brussels, pp.116 p.

Ankerman, D., Large, R. 1974. Soil and Plant Analysis. Tech. Bull. A \& L Agricultural Laboratories, Inc, New York, United States.

Arif, M., Waqas, M., Nawab, K., Shahid, M. 2007. Effect of seed priming in $\mathrm{Zn}$ solutions on chickpea and wheat. Afri. Crop Sci. Pro. 8, 237-240.

Beyene, S., Worku, W., Abate, B., Kumsa, W., Asefa, M. 2013. Participatory Chickpea and Lentil Variety Selection. Final Technical Report to International Development Research Center. Hawassa University, Ethiopia.
Brennan, R.F., Bolland, M.D., Siddique, K.H. 2001. Response of cool-season grain legumes and wheat to soil applied Zinc. J. Plant Nutr. 24, 727-741.

Bueckert, R.A., Thavarajah, D., Pushparajah, T., Pritchard, J. 2011. Phytic acid and mineral micronutrients in feld-grown chickpea (Cicer arietinum L.) cultivars from western Canada. Eur. Food Res. Technol. 233, 203-212.

Cakmak, I. 2002. Plant nutrition research: Priorities to meet human needs for food in sustainable ways. Plant and Soil. 247, 3-24.

Cakmak, I. 2008. Enrichment of cereal grains with zinc: Agronomic or genetic biofortification? Plant and Soil. 302, 1-17.

Cakmak, I. 2010. Biofortification of cereals with zinc and iron through fertilization strategy. In: Micronutrients in Soils and Plants in Relation to Crop and Human Health. 19th World Congress of Soil Science, Brisbane, 1-6 August 2010.

Canadian International Food Security Research Fund (CIFSRF). 2013. Improving Nutrition in Ethiopia Through Plant Breeding and Soil Management. http:/www.idrc.ca.

Central Statistics Agency (CSA). 2015. Agricultural Sample Survey for 2014 / 2015(2007 E.C.), volume I: Report on area and production of major crops (private peasant holdings, meher season). Addis Ababa, Statistical Bulletin. 578.

Diapari, M., Sindhu, A., Bett, K., Deokar, A., Warkentin, T.D., Tar'an, B. 2014. Genetic diversity and association mapping of iron and zinc contents in chickpea (Cicer arietinum L.). Genome. 57(8), 459-468.

Eichert, T., Burkhardt, J. 2001. Quantification of stomatal uptake of ionic solutes using a new model system. J. Expl. Bot. 52, 771-781.

Fageria, N.K., Barbosa Filho, M.P., Moreira, A., Guimarães, C.M. 2009. Foliar fertilization of crop plants. J. Plant Nutr. 32, 1044-1064. 
Food and Agriculture Organization of the United Nations (FAO). 2015. FAOSTAT. Available at: http:// faostat3.fao.org/home/index.html\# Download

Franke, W. 1967. Mechanisms of foliar penetration of solutions. Annual Rev. Plant Physio. 18, 281-300.

Gomez, A., Gomez, A. 1984. Statistical Procedures for Agricultural Research. John Wiley and Sons, Inc. pp. 467-477.

Guo, J.X., Feng, X.M., Hu, X.Y., Tian, G.L., Ling, N.,Wang, J.H., Shen, Q.R., Guo, S.W. 2016. Effects of soil zinc availability, nitrogen fertilizer rate and zinc fertilizer application method on zinc biofortification of rice. J. Agric. Sci. 154, 584-597.

Harris, D., Rashid, A., Miraj, G., Arif, M., Yunas, M. 2008. On-farm seed priming with zinc in chickpea and wheat in Pakistan. Plant Soil. 306, 3-10.

Hawando, T. 1987. Soil and climatic stresses on chickpea production in Ethiopia. In: Adaptation of Chickpea and Pigeonpea to Abiotic Stresses. Proceedings of the Consultants Workshop, ICRISAT, India, pp. 159-167.

Hortz, C., Brown, K. 2004. Assessment of the risk of zinc deficiency in populations and options for its control. Food Nutr. Bull. 25, 94-204.

Johnson, E., Lauren, G., Welch, R., Duxbury, J. 2005. A comparison of the effects of micronutrient seed priming and soil fertilization on the mineral nutrition of chickpea (Cicer arietinum), lentil (Lens culinaris), rice (Oryza sativa) and wheat (Triticum aestivum) in Nepal. Expl.Agric. 41, 427-448.

Kaya, M., Zeliha, K., Albrahin, E. 2009. Phytase activity, phytic acid, zinc, phosphorus and protein contents in different chickpea genotypes in relation to nitrogen and zinc fertilization. Afr. J. Biotechnol. 8 (18), 4508-4513.
Khan, H.R., McDonald, G.K., Rengel, Z. 2000. Response of chickpea genotypes to zinc fertilization under field conditions in South Australia and Pakistan. J. Plant Nutr. 23(10), 1517-153.

Lindsay, L., Norvell, W. 1978. Development of DTPA soil test for zinc, iron, manganese and copper. Soil Sci. Soc. Am. J. 42,421-428.

Liu, H., Gan, W., Rengel, Z., Zhao, P. 2016. Effects of zinc fertilizer rate and application method on photosynthetic characteristics and grain yield of summer maize. J. Soil Sci. Plant Nutr. 16 (2), 550-562.

Mayer, J.E., Pfeiffer, W.H., Beyer. P. 2008. Biofortified crops to alleviate micronutrient malnutrition. Curr. Opin. Plant Biol. 11, 166-170.

Márquez-Quiroz, C., De-la-Cruz-Lázaro, E., OsorioOsorio, R., Sánchez-Chávez, E. 2015. Biofortification of cowpea beans with iron: iron's influence on mineral content and yield. J. Soil Sci. Plant Nutr. 15 (4), 839-847.

Melash, A.A., Mengistu, D. K., Aberra, D.A. 2016. Linking agriculture with health through genetic and agronomic biofortification. Agric. Sci. 7, 295-307.

Ministry of Agriculture (MoA). 2014. Animal and Plant Health Regulatory Directorate. Crop Variety Register. Issue no. 17. Addis Ababa. pp. 93-96.

Mohammad, N., Mansoureh, K. and Hossein, A. 2011. Zn-foliar application influence on quality and quantity features in Phaseolous vulgaris under different levels of $\mathrm{N}$ and $\mathrm{K}$ fertilizers. Adv. Environ. Biol. 5(5), 839-846.

Mousavi, S.R. 2011. Zinc in crop production and interaction with phosphorus. Aust. J. Basic \& Appl. Sci. 5(9), 1503-1509.

National Meteorology Agency (NMA). 2013. Available at: http://www.ethiomet.gov.et/ 
Nubé, M., Voortman, R.L. 2006. Simultaneously addressing micronutrient deficiencies in soils, crops, animal and human nutrition: opportunities for higher yields and better health. Staff Working Paper, WP - 06 - 02.Center for World Food Studies, Amsterdam.

Nwokolo, E., Smartt, J. 1996. Food and Feed from Legumes and Oilseeds. Chapman and Hall Publishing. pp. 82- 84 .

Olsen, S.R., Sommers, L.E. 1982. Phosphorus. In: A.L. Page, R.H. Miller (eds). Methods of Soil Analysis. Part 2. 2nd ed. Agronomy Monograph 9, ASA and SSSA, Madison, WI. pp. 403-430.

Pathak, G. C., Gupta, B., Pandey, N. 2012. Improving reproductive efficiency of chickpea by foliar application of zinc. Braz. J. Plant Physiol. 24(3), 173-180.

Ray, H., Bett, K., Tar'an, B.,Vandenberg, A., Thavarajah, D., Warkentin, T. 2014. Mineral micronutrient content of cultivars of field Pea, chickpea, common bean, and lentil grown in Saskatchewan, Canada. Crop Sci. 54, 1-11.
Rengel, Z., Batten, G.D., Crowley, D.E. 1999. Agronomic approaches for improving the micronutrient density in edible portions of field crops. Field Crops Res. 60, 27-40.

SAS Institute Inc. 2008. SAS/STAT 9.2. User's Guide. Cary, NC: SAS Institute Inc.

Shivay, Y.S. 2014. Genetic variability for zinc use efficiency in chickpea as influenced by zinc fertilization. International Journal of Bio-resource and Stress Management. 5(1), 031-036.

Thavarajah, D., Thavarajah, P., Sarker, A., Vandenberg, A. 2009. Lentils (Lens culinaris Medikus Subspecies culinaris): A whole food for increased iron and zinc intake. J. Agric. Food Chem. 57, 5413-5419.

United Nations Children's Emergency Fund (UNICEF). 2014. Nutrition. Available at: www.unicef. org/ethiopia.

Walkley, A. 1947. A critical examination of a rapid method for determining organic carbon in soils: Effect of variation in digestion conditions and of organic soil constituents. Soil. Sci. 63, 251-263.

Yadegari, M. 2016. Effect of micronutrients foliar application and biofertilizers on essential oils of lemon balm. J. Soil Sci. Plant Nutr. 16(3), 702-715. 